\title{
Faktor Risiko Sekuele Meningitis Bakterial pada Anak
}

\author{
Muriana Novariani, Elisabeth Siti Herini, Suryono Yudha Patria \\ Bagian/SMF Ilmu Kesehatan Anak FK-UGM/RSUP Dr. Sardjito, Yogyakarta
}

\begin{abstract}
Latar belakang. Mortalitas akibat meningitis bakterial menurun dengan ditemukan antibotik yang poten dan penanganan yang baik pada saat pasien kritis. Walaupun demikian, sekuele akibat meningitis bakterial masih tinggi, sekitar 50\%-65\% di negara berkembang.

Tujuan. Mengetahui faktor risiko yang terkait dengan sekuele pada pasien meningitis bakterial yang bertahan hidup.

Metode. Penelitian kasus kontrol dilakukan di RSUP Dr. Sardjito, RSUD Banyumas dan RSU Suradji Tirtonegoro Klaten. Kasus adalah pasien yang terdiagnosis meningitis bakterial pada tahun 2003 - 2006 yang hidup dengan sekuele. Kontrol adalah pasien meningitis bakterial yang hidup tanpa sekuele. Data diambil dari catatan medis, luaran ditetapkan setelah 6 bulan.

Hasil. Terdapat 78 pasien yang memenuhi kriteria inklusi. Hasil analisis multivariat menunjukkan bahwa faktor risiko yang terkait dengan meningitis bakterial adalah kejang $\geq 30$ menit saat masuk rumah sakit (OR 4,29; IK 95\% 1,38-12,99), PCS (Pediatrics Coma Scale) $\leq 8$ (OR 3,76; IK 95\% 1,15-12,28), dan kejang yang tidak terkontrol $\geq 72$ jam (OR 5,24; IK 95\% 1,49-18,43). Onset - gejala $\geq 48$ jam mempunyai OR 2,43 (IK 95\% 0,73-8,13).
\end{abstract}

Kesimpulan. Kejang $\geq 30$ menit saat masuk rumah sakit, $\mathrm{PCS} \leq 8$, dan kejang yang tidak terkontrol $\geq 72$ jam merupakan faktor risiko yang indipenden untuk menimbulkan sekuele. (Sari Pediatri 2008; 9(5):342-7).

Kata kunci: meningitis bakterial, sekuele, anak, kasus kontrol

I

nfeksi sistem saraf pusat (SSP) mengakibatkan beban yang berat bagi sumber daya di pelayanan kesehatan di setiap negara. ${ }^{1,2}$ Dengan berkem bangnya antibiotik yang poten, perbaikan

\footnotetext{
Alamat korespondensi

Dr. Muriana Novariani, SpA. Bagian Ilmu Kesehatan Anak, RSUP Dr. Sardjito, Jl. Kesehatan no 1 Yogyakarta. Fakultas Kedokteran Universitas Gadjah Mada. Telepon (0274) 587333 psw 301, Fax.: 0274583745. E-mail: paediatric_gmu@yahoo.com
}

penanganan pasien kritis dan perkembangan terapi adjuvan baru menyebabkan angka kematian akibat meningitis bakterial menurun.,

Sekuele neurologis merupakan komplikasi meningitis bakterial yang paling sering terjadi. Komplikasi ini mencapai sekitar 50\%-65\% di negara berkembang. Keterlambatan diagnosis dan terapi, serta berbagai kendala di negara berkembang merupakan faktor yang mempunyai kontribusi dalam menimbulkan sekuele. ${ }^{5}$ Faktor risiko penyebab timbulnya sekuele 
di negara berkembang berbeda-beda. Beberapa sekuele terjadi pada awal penyakit dan sebagian menetap, sehingga menimbulkan gangguan perkembangan akibat disabilitas. ${ }^{2,5}$

Pada meningitis bakterial, akan terjadi hipoksia, produk neurotoksik bakteri, dan gabungan dari mediator akan menyebabkan kerusakan neuron. Kerusakan neuron disebabkan bakteri atau derivat leukosit, dan elemen toksik akhir adalah radikal bebas. Oksigen reaktif intermediate dan nitrogen reaktif inetrmediate yang mempunyai efek toksik langsung pada neuron. Aktivasi sel yang mengalami apoptosis dan nekrosis menyebabkan kerusakan sel neuronal yang menyebabkan sekuele neurologis yang menetap atau bahkan kematian. ${ }^{6,7,8}$

Beberapa faktor risiko terkait dengan prognosis pasien meningitis bakterial adalah perjalanan klinis yang disebabkan oleh sifat patogen (spesifikasi bakteri atau peningkatan jumlah resistensi obat), derajat gejala klinis awal, (komplikasi SSP, misalnya edema otak, hidrosefalus, abses otak, mempengaruhi vaskularisasi serebrovaskular), usia, durasi antara gejala awal timbul dengan pemberian terapi antibiotik yang intensif, tipe dan dosis antibiotik. ${ }^{9,10,11}$ Kejang $\geq 30$ menit dan kejang yang tidak terkontrol mempunyai kemungkinan sekuele pada meningitis bakterialis yang lebih besar. ${ }^{12,13}$

Penelitian bertujuan untuk mengetahui faktorfaktor yang terkait dengan sekuele yang terjadi pada anak dengan meningitis bakterial yang bertahan hidup. Identifikasi faktor risiko sekuele sangat penting untuk memprediksi prognosis pasien meningitis bakterial.

\section{Metode}

Penelitian dilakukan di bangsal unit perawatan intensif anak atau pediatric intensive care unit (PICU) poliklinik Instalasi Kesehatan Anak RSUP Dr. Sardjito Yogyakarta dan RS Jaringan Pendidikan (RSU Banyumas dan Klaten) mulai tahun 2003- 2005 sampai diperoleh subjek sebesar jumlah yang diinginkan.

Penelitian menggunakan rancangan kasus kontrol. Kasus adalah pasien meningitis bakterial yang hidup dengan sekuele. Kontrol adalah pasien meningitis bakterial yang hidup tanpa sekuele. Luaran utama yang dinilai adalah timbulnya sekuele yaitu hidrosefalus, kuadriplegia atau hemiplegia, tuli, epilepsi dan gangguan perkembangan global.

Meningitis bakterial adalah peradangan selaput otak yang ditandai dengan demam dengan awitan akut $\left(>38,5^{\circ} \mathrm{C}\right.$ rektal atau $38^{\circ} \mathrm{C}$ aksilar) disertai dengan satu atau lebih gejala kaku kuduk, penurunan kesadaran, dan tanda Kernig atau Brudzinski. ${ }^{14}$ Kriteria laboratorium apabila biakan liquor cerebro spinalis (LCS) positif atau biakan negatif namun jumlah sel $>10 / \mathrm{mm}^{3}$, protein $>0,6$ $\mathrm{g} / \mathrm{l}$, perbandingan kadar glukosa dalam LCS dan darah $<0,5$ dan morfologi sel PMN $>60 \% .{ }^{15}$

Kriteria inklusi anak umur $>1$ bulan -15 tahun dengan kecurigaan meningitis, berdasar klinis, analisis LCS, kultur / sediaan apus Gram dan catatan medis lengkap. Pasien tidak diikutsertakan dalam penelitian apabila terdapat meningitis berulang, tidak dilakukan Fungsi Lumbal (LP) > 24 jam setelah masuk rumah sakit, telah mendapat terapi antibiotik selama 5 hari sebelumnya, terdapat kelainan kongenital/malformasi yang berat.

Perkiraan proporsi sekuele pada kelompok kontrol adalah $15 \%$, power yang diinginkan $80 \%$, rasio kasus dengan kontrol 1:1. Besar sampel dihitung berdasarkan perbedaan proporsi sehingga didapatkan jumlah sampel minimal 36 subjek untuk masing-masing kelompok. ${ }^{16,17}$

Jenis sekuele ditentukan dari follow up dari catatan medik poliklinik. Bila pasien tidak datang kembali berobat, dilakukan pemantauan melalui telepon dan surat. Peneliti mengirimkan surat yang berisi pertanyaan sederhana dan permohonan izin untuk wawancara melalui telepon. Persetujuan tersebut dikirim melalui pos yang dilengkapi dengan amplop dan perangko balasan kepada peneliti.

Data berskala numerik dianalisis dengan uji $\mathrm{t}$ sedangkan data berskala nominal mempergunakan analisis uji kai kuadrat. Dilakukan analisis bivariat dan multivariat untuk faktor prediktor yang mempengaruhi hasil. Asosiasi berbagai faktor prognostik dianalisis dengan regresi logistik multipel. Pengukuran hubungan antara faktor prognostik dan luaran ditampilkan dengan rasio odds/odds ratio (OR) dan interval kepercayaan (IK 95\%).

\section{Hasil}

Dari seluruh rumah sakit yang diteliti didapatkan 128 kasus catatan medis, 78 kasus memenuhi kriteria inklusi. Sebagian besar kasus yang dieksklusi adalah 
pasien yang minta pulang paksa pada saat kondisi pasien masih memerlukan terapi yang adekuat, pungsi lumbal tidak dilakukan 24 jam dan pasien mengalami kelainan kongenital yang berat seperti hidransefali, sindrom rubella kongenital dan epilepsi refrakter (Tabel 1).

Perbandingan antara laki-laki dan perempuan adalah $1,3: 1$. Proporsi umur dan jenis kelamin antara dua kelompok menunjukkan proporsi yang seimbang. Tabel 3 menunjukkan jumlah pasien yang mengalami sekuele. Jumlah disajikan dalam persentase, dibanding- kan seluruh kelompok kasus. Beberapa pasien mengalami lebih dari satu sekuele. Jenis sekuele paling banyak gangguan neuromotor termasuk hemiparesis atau tetraparesis spastik, sekuele lain epilepsi dan keterlambatan global masing-masing adalah $21 \%$ dan $23 \%$.

Tabel 4 menunjukkan analisis bivariat faktor risiko antara kelompok kasus dan kelompok kontrol. Umur $\leq 1$ tahun tidak berbeda bermakna dengan umur $>1$ tahun (OR 1, IK 95\% 0,41 - 2,34). Lama kejang menunjukkan perbedaan bermakna antara kelompok,

Tabel 1. Kasus meningitis bakterial di tiga rumah sakit pendidikan selama 2003-2006.

\begin{tabular}{lccccc}
\hline \multicolumn{1}{c}{ Rumah Sakit } & Jumlah kasus & Eksklusi & Meninggal & $\begin{array}{c}\text { Hidup dengan } \\
\text { sekuele }\end{array}$ & $\begin{array}{c}\text { Hidup tanpa } \\
\text { sekuele }\end{array}$ \\
\hline RSUP Dr. Sardjito & 71 & 5 & 10 & 25 & 36 \\
RSU Dr. Suradji & 16 & 3 & 5 & 9 & 2 \\
Tirtonegoro Klaten & 10 & 4 & 4 & 5 & 1 \\
RSUD Banyumas & 97 & 12 & 19 & 39 & 39 \\
\hline Jumlah & & & & & \\
\hline
\end{tabular}

Tabel 2. Karakteristik pasien meningitis bakterial

\begin{tabular}{lll}
\hline Karakteristik & $\begin{array}{l}\text { Dengan sekuele } \\
\mathrm{n}=39\end{array}$ & $\begin{array}{l}\text { Tanpa sekuele } \\
\mathrm{n}=39\end{array}$ \\
\hline $\begin{array}{l}\text { Umur (bulan) } \\
\text { Jenis kelamin }\end{array}$ & $36,64 \pm 14,6$ & $37,9 \pm 15,86$ \\
- Laki - laki (rerata, SB) & $21(26,9)^{*}$ & $23(29,5)$ \\
- Perempuan & $18(23,1)$ & $16(20,5)$ \\
Penyakit penyerta (rerata, SB) & & \\
- Pneumonia & $14(17,9)^{*}$ & $13(16,7)$ \\
- Diare & $9(11,5)$ & $13(16,7)$ \\
- Otitis media & $5(6,4)$ & $4(5,1)$ \\
Onset antara durasi - gejala & $3,64 \pm 1,94$ & $3,23 \pm 1,27$ \\
Analisis LCS (mg\%, rerata, SB) & & \\
- Sel & $1545,05 \pm 896,75$ & $391,36 \pm 157,9$ \\
- Protein & $171,79 \pm 89,96$ & $119,72 \pm 58,98$ \\
- Glukosa & $46,77 \pm 30,8$ & $59,56 \pm 36,8$ \\
Darah rutin (mg\%, rerata, SB) & & \\
- Hb & $10,64 \pm 1,79$ & $10,71 \pm 1,5$ \\
- AL & $12.366 \pm 219,7$ & $12.685 \pm 694,82$ \\
- AT & $304.794,87 \pm 242,55$ & $269.871,29 \pm 114.893,8$ \\
Durasi antibiotik (hari) & $14,66 \pm 8,78$ & $9,69 \pm 4,76$ \\
Riwayat antibiotik sebelumnya & $18(23,1)$ & $16(20,5)$ \\
Status neurologis (rerata, SB) & & \\
- Kaku kuduk & $20(50)$ & $20(50)$ \\
- Meningeal sign & $26(53,3)$ & $23(46,9)$ \\
- Refleks fisiologis & $32(51,6)$ & $30(48,4)$ \\
- Refleks patologis & $32(51,6)$ & $30(48,4$ \\
\hline
\end{tabular}


yaitu lama kejang $\geq 30$ menit mempunyai OR 5,33 (IK 95\% 1,9 - 14,28). Jumlah skor koma pediatrik menunjukkan perbedaan bermakna antara dua kelompok dengan OR 6,57 (IK 95\% 2,3-18,54) untuk pediatric coma scale (PCS) $\leq 8$. Jumlah skor PCS pada kelompok sekuele $6,3( \pm 2,9)$ dan 8,24 $( \pm 2,38)$ pada kelompok luaran baik $(\mathrm{p}=0,003)$.

Kejang yang tidak terkontrol pada saat perawatan pada kelompok dengan sekuele mempunyai OR 8,8 (IK 95\% 2,84-27,30). Syok septik tidak mempunyai hubungan yang signifikan antara 2 kelompok (OR 1,37; IK 95\% 0,28-6,57). Terdapat perbedaan bermakna antara onset gejala dengan pemberian terapi,

Tabel 3. Sekuele pada pasien meningitis bakterial

\begin{tabular}{lc}
\hline Sekuele & Jumlah (\%) \\
\hline Tetrapasesis spastik & $19(50)$ \\
Hidrosefalus & $3(7)$ \\
Buta & $4(10)$ \\
Tuli & $3(8)$ \\
Epilepsi & $8(21)$ \\
Global developmental delay & $9(23)$ \\
\hline
\end{tabular}

dengan OR 2,6 (IK 95\% 1,03-6,59). Jenis antibiotik mempunyai perbedaan bermakna. Pasien yang mendapatkan antibiotik lini kedua mempunyai risiko untuk terjadi sekuele dengan OR 2,56 (1,03-6,40).

Hasil analisis regresi logistik multivariat faktor risiko sekuele meningitis bakterial adalah lama kejang $\geq 30$ menit, kejang tak terkontrol $\geq 72$ jam, skor PCS yang rendah $(\leq 8)$, dan onset antara gejala dan pemberian terapi adekuat. Dari regresi logistik multivariat ternyata kejang $\geq 30$ menit mempunyai risiko terjadinya sekuele dengan OR 4,29 (IK 95\% 1,38-12,99), PCS $\leq 8$ mempunyai OR 3,76 (IK 95\% $1,15-12,28)$ dan kejang tak terkontrol $>72$ jam mempunyai OR 5,24 (IK 95\% 1,49-18,430), sedangkan durasi antara onset dan pemberian terapi tidak mempunyai perbedaan bermakna, OR 2,43 (IK 95\% 0,73-8,13).

\section{Pembahasan}

Sekuele yang terjadi sebagian besar adalah tetraplegi spastik (50\%), gangguan perkembangan global (23\%), epilepsi (21\%), kebutaan (10\%), hidrosefalus (7\%) dan

Tabel 4 . Analisis bivariat variabel dikotom prognosis meningitis bakterial

\begin{tabular}{lccc}
\hline Variabel & $\begin{array}{c}\text { Prognosis buruk } \\
\mathrm{n}=39\end{array}$ & $\begin{array}{c}\text { Prognosis baik } \\
\mathrm{n}=39\end{array}$ & OR (IK 95\%) \\
\hline $\begin{array}{l}\text { Umur (tahun) } \\
\leq 1\end{array}$ & $20(25,6)$ & $20(25,6)$ & $1(0,411-2.430)$ \\
$>1$ & $19(24,4)$ & $19(24,4)$ & \\
Kejang (menit) & & & \\
$\geq 30$ & $24(30,8)$ & $9(11,5)$ & $5,33(1,9-14,28)$ \\
$<30$ & $15(49,2)$ & $30(38,5)$ & \\
Pediatric Coma Scale & & & \\
$\leq 8$ & $23(29,5)$ & $7(9,0)$ & $6,57(2,3-18,54)$ \\
$>8$ & $16(20,5)$ & $32(41,0)$ & \\
Syok septik & $4(5,1)$ & $3(3,8)$ & $1,37(0,28-6,57)$ \\
Ya & $35(44,9)$ & $36(41,0)$ & \\
Tidak & & & \\
Kejang tak terkontrol $>72$ jam & $22(28,2)$ & $5(6,4)$ & $8,8(2,84-27,30)$ \\
Ya & $17(21,8)$ & $34(43)$, & \\
Tidak & & & \\
Onset antara gejala-terapi (jam) & $35(42,2)$ & $7(12,5)$ & $2,6(1,03-6,59)$ \\
$\geq 48$ & $4(5,1)$ & $32(41,0)$ & \\
$<48$ & & & \\
Jenis antibiotik & $25(32,1)$ & $15(19,2)$ & $2,56(1,03-6,40)$ \\
Antibiotik lini kedua & $14(17,9)$ & $24(30,8)$ & \\
Antibiotik lini pertama & & & \\
\hline
\end{tabular}


Tabel 5. Faktor prognostik berdasarkan analisis regresi logistik multipel

\begin{tabular}{lcc}
\hline Faktor prognostik & OR & IK (95\%) \\
\hline $\begin{array}{l}\text { Kejang (menit) } \\
\quad 30\end{array}$ & 4,29 & $1,38-12,99$ \\
$\quad<30$ & 1 & \\
Kejang tak terkontrol > 72 jam & & \\
$\quad$ Ya & 5,24 & $1,49-18,43$ \\
$\quad$ Tidak & 1 & \\
Pediatric Coma Scale & & \\
$\quad \leq 8$ & 3,76 & $1,15-12,28$ \\
$\quad>8$ & 1 & \\
Durasi antara onset - terapi & & \\
$\quad \geq 48$ & 2,43 & $0,73-8,13$ \\
$<48$ & 1 & \\
\hline
\end{tabular}

ketulian (8\%). Hasil hampir sama serupa dengan penelitian yang dilakukan Urowayino $\mathrm{dkk}^{5}$ di Afrika, pasien yang mengalami sekuele $65,3 \%$, gangguan neuromotor $31 \%$, gangguan perkembangan bicara $25 \%$, kejang berulang $22 \%$, retardasi mental $22 \%$, gangguan visual $19 \%$. Kejadian hidrosefalus lebih rendah dibandingkan dengan di Afrika 28\%. Kemungkinan kejadian hidrosefalus lebih besar, namun karena tidak semua pasien dilakukan pemeriksaan CT-scan atau USG kepala pasca meningitis maka hidrosefalus tidak terdeteksi. Hal ini disebabkan keterbatasan fasilitas dan karena pemeriksaan CT-scan kepala atau USG kepala di RS DR. Sardjito bukan merupakan prosedur rutin. Dibandingkan dengan mortalitas di Jepang lebih rendah $(3,9 \%)$ dan sekuele neurologis $31,4 \% .{ }^{18}$ Angka kematian di negara maju lebih rendah karena terdapat beberapa faktor, antara lain cakupan imunisasi tinggi terhadap bakteri penyebab meningitis, tindakan diagnositik serta fasilitas perawatan yang lebih baik.

Pada penelitian ini prediktor sekuele meningitis bakterial adalah status konvulsivus (lama kejang $>30$ menit) dan penurunan kesadaran berat (PCS <8). Akapede dkk. ${ }^{19}$ menemukan bahwa umur kurang atau sama dengan dua tahun, durasi sakit lebih dari 7 hari, terapi antibiotik, defisit nervus fokal, postur abnormal merupakan faktor yang mempengaruhi timbulnya sekuele neurologis, syok atau koma.

Penelitian yang dilakukan oleh Bedford dkk, ${ }^{4}$ variable umur merupakan prediktor penting untuk menentukan prognosis meningitis bakterial. Prognosis yang penting adalah meningkatnya risiko disabilitas pada waktu umur 5 tahun (OR 10.33, IK 95\% 6.616.10). Hasil penelitian yang dilakukan Farag dkk, ${ }^{20}$ anak yang menderita meningitis mempunyai risiko prognosis yang buruk 7,7 (IK 95\% 8.1-20.3). Pada penelitian ini umur tidak mempunyai perbedaan yang bermakna. ${ }^{2}$ Secara teoritis, plastisitas jaringan otak pada usia kurang dari satu tahun baik sehingga bila terjadi cedera atau kerusakan otak pada usia tersebut, sel neuron masih mampu untuk pulih kembali (reversible).

Biakan positif ditemukan pada $32,5 \%$ pasien dengan hasil paling banyak Staphylococcus pada 15 pasien (55\%) dan Streptococcus pada 5 (15\%). Penelitian yang dilakukan Kirimi dkk, ${ }^{10}$ menemukan mikroorganisme Staphylococcus dalam biakan likuor rere brospinalis. Penelitian Farag dkk ${ }^{2}$ menunjukkan penyebab meningitis bakterial paling banyak $H$. influenzae, $N$. meningitidis dan $S$. pneumonia. ${ }^{2}$ Teknik biakan merupakan keterbatasan penelitian ini, karena media yang digunakan untuk biakan cairan serebrospinal yang ideal adalah agar darah domba 5\% yang diperkaya dengan agar coklat, sedangkan di RSUP dr Sardjito menggunakan media Bactex. Selain itu terapi antibiotik yang diberikan sebelum dilakukan fungsi lumbal dapat menurunkan sensitivitas biakan, terutama bila diberikan intravena atau intramuskular. ${ }^{21,22,23}$ Pada penelitian ini, $37 \%$ pasien telah mendapatkan antibiotik intravena dari rumah sakit sebelumnya.

\section{Kesimpulan}

Faktor risiko bebas untuk terjadinya sekuele pada anak yang mengalami meningitis bakterial adalah kejang $\geq 30$ menit, PCS $\leq 8$ dan kejang tidak terkontrol yang berlangsung $>72$ jam.

\section{Daftar Pustaka}

1. Chong HT, Tan CT. Epidemiology of central nervous system infections in Asia, recent trends. Neurology Asia 2005; 10:7-11.

2. Farag HF, Abdel-Fattah MM, Youssri AM. Epidemiological, clinical and prognostic profile of acute bacterial meningitis among children in Alexandria, Egypt. Indian J Clin. Microbiol 2005; 23:95-101.

3. Swartz MN. Bacterial meningitis - a view of the past 90 years, N Engl J Med 2004; 351:1826-8. 
4. Bedford H, Louvois J, Halket S, Peckham C, Hurley R, Harvey D. Meningitis in infancy in England and Wales: Follow up at age 5 years, Be Med J, 2001; 323:15 .

5. Urowayino OE, Afolabi LF, Chinyere EK, Olufunmilayo GA. Neurological sequelae in childrem with pyogenic meningitis in a tertiary centre in Lagos (Nigeria), African J Neurol Sci, 2004; 23:31-8

6. Weil ML and Levin M. Infections of the nervous system Dalam: Textbook of Child Neurology, Menkes, J.H, penyunting. Edisi ke-7. Baltimore Maryland: Wiliam \& Wilkins; 2005. h. 433-7.

7. Mehta N, Pollard AJ. Speciate feature meningitisbacterial meningitis, Hosp Pharmacist, 1999;6:256-62.

8. Liorens XS, Ramilo O, Mustafa M, Mertsola J, McCracken G. Molecular patophysiology of bacterial meningitis: current concepsts and therapeutic implications. Pediatrics 1990; 116:671-81.

9. Chin RF, Neville BG, Scott RC. Meningitis is a common cause of convulsive status epilepticus with fever. Archs Dis Child 2005; 90:66-9.

10. Kilpi T. Length of prediagnostic history related to the course and sequelae of childhood bacterial meningitis. Pediatr Inf Dis J 1993; 12:184-8.

11. Kirimi E, Tuncer O, Arslan S, Atas B, Husyein C, Uner A. Prognostic factor in children with purulent meningitis in Turkey. Acta Med Okayama, 2003; 57:39-44.

12. Baraff LJ, Lee SI, Schriger DL. Outcomes for bacterial meningitis in children: a metaanalysis. Pediatr Infect Dis J 1993; 12:389-94.

13. Riviello JJ, Ashwal S, Hirtz D, Glauser T, Ballaban-Gil K, Kelley dkk. Practice parameter: Diagnostic assessment of the child with status epilepticus (an evidence-based review): Report of the Quality Standards Subcommittee of American Academy of Neurology and the Practice Committee of the Child the Neurology Society. Neurology 2006; 67:1542-50

14. Rosman NP, Peterson DB, Kaye EM, Colton T. Seizure in bacterial meningitis, prevalence, patterns, pathogenesis and prognosis, Pediatr Neurol 1985;1:278-85.

15. Bashir HE, Laundy M, Booy R. Diagnosis and treatment of bacterial meningitis, Archs Dis Child 2003; 88:615-20.

16. Communicable Disease Surveillance. Communicable disease profile for tsunami affected areas: Indonesia, WHO, CDS, 2005.

17. Schutte C-M, van der Meyden CH. A prospective study of Glasgow Coma Scale (GCS), age, CSF-neutrophil count, and CSF-protein and glucose levels as prognostic indicators in 100 adult patients with meningitis. J Infect 1998; 37:112-5

18. Aronin J. Meningitis, hypotension, altered mental status and seizure at admission increased the risk of dying in hospital. Ann Intern Med 1998; 129:829-69.

19. Takayanagi M, Yamamoto K, Nakagawa H, Inuma K. Factors associated with the prognosis of bacterial meningitis in children. No To Hattatsu. 1997; 29:291-7.

20. Akapede GO, Jalo I, Dawodo SO. A revised clinical methods for assesment of severity acute bacterial meningitis. Ann Trop Pediatr 2002; 22:33-44.

21. Anderson V, Catroppa C, Morse S, Haritou F, Rosenfeld. Functional plasticity or vulnerability after early brain injury? J Pediatr 2005; 116:1374-82.

22. Kanegaye JT, Seliemanzaden P, Bradley JS. Lumbar puncture in pediatric bacterial meningitis : defining the time interval of recovery of cerebrospinal; fluid pathogenesis after parenteral antibiotic pretreatment. Pediatr 2001; 108:1169-74.

23. Kaplan SL. Clinical presentations, diagnosis, and prognostic factors of bacterial meningitis. Infect Dis Clin North Am 1999; 13:579-94.

24. Coant PN, Kornberg AE, Duffy LC, Dryja DM, Hassan SM. Blood culture results as determinants in the organism identification of bacterial meningitis. Pediatr Emerg Care 1992; 8:200-5. 